\title{
NOVEMBER MEETING IN ALBUQUERQUE
}

The six hundred fifty-first meeting of the American Mathematical Society was held on Saturday, November 18, 1967, at the University of New Mexico in Albuquerque, New Mexico. There were 67 registrants at this meeting, 52 of whom were members of the Society.

-By invitation of the Committee to Select Hour Speakers for Far Western Sectional Meetings, there were two invited hour addresses at the meeting. Professor R. K. Getoor of the University of California, San Diego spoke on Some recent developments in Markov processes. Professor Getoor was introduced by Professor J. R. Blum. Professor Basil Gordon of the University of California, Los Angeles, presented an address entitled Some recent developments in the theory of partitions. He was introduced by Professor D. W. Dubois.

There were two sessions for contributed papers with Professor Ray Mines and Professor H. P. Kuang presiding.

Las Cruces, New Mexico

R. S. PIERCE

Associate Secretary 